\title{
PERCEPÇÕES DA PAISAGEM DA SERRA DA CAPIVARA-PI
}

\section{PERCEPTIONS OF THE LANDSCAPE OF THE SERRA DA CAPIVARA-PI}

\author{
Diva Maria Freire Figueiredo \\ Myriam Bahia Lopes
}

Apoio: FAPEMIG APQ-02775-15

\begin{abstract}
Resumo
Neste artigo lançamos mão da geografia e da história para realizar um estudo da paisagem da Serra da Capivara. A revisão da literatura científica e de fontes documentais da UNESCO, IPHAN, reportagens impressas, audiovisuais e registros orais editados e publicados compõem um mosaico acerca das mudanças físicas e percepções da paisagem da Serra da Capivara. Os relatos de antigos moradores sobre essa paisagem, hoje desabitada e tutelada pelo Estado, assim como as visões dos pesquisadores, nos auxiliam a compreender a singularidade desse lugar. Nesse artigo, indicamos o encontro de quatro campos envolvidos no tema: história, patrimônio cultural, ciência arqueológica e proteção ao meio ambiente. A Serra da Capivara é objeto de políticas públicas de preservação do patrimônio cultural e natural. E a patrimonialização está presente nas abordagens dessa paisagem. No entanto, sua interpretação em documentos relacionados à tutela nacional e internacional do patrimônio revela a permanência de ambiguidades. O uso do binômio natureza/cultura como fundamento dos textos precisa ser superado.

Palavras-chave: Lugar. Patrimônio. Paisagem. Percepção.
\end{abstract}

\section{AbStRACt}

In this article, we use Geography and History to undertake a study of the landscape of Serra da Capivara. The review of the scientific literature and documentary sources of UNESCO, IPHAN, printed reports, audiovisual and edited and published oral records integrate a mosaic concerning physical changes and perceptions of the landscape of the Serra da Capivara. The reports concerning this landscape, today uninhabited and protected by the State, made by former residents together with the researchers' views, help us to understand the uniqueness of this place. For this study, other disciplines are equally relevant in the intersection or meeting of four involved fields: history, cultural heritage, archaeological science and environmental protection. The Serra da Capivara is the object of public policies for the preservation of cultural and natural heritage. As a result, patrimonialization has a particular influence on the prism of approaches to the studied landscape. However, its interpretation in documents related to the national and international protection of the heritage reveals the permanence of ambiguities. The still persistent dichotomy among researchers and in these records between nature and culture needs to be overcome.

Keywords: Place. Heritage. Landscape. Perception. 


\section{IntRodução}

O texto trata o Parque Nacional da Serra da Capivara (PARNA SC) como patrimônio. Seus sítios arqueológicos são bens da União e protegidos pela Lei $n^{\circ} 3924$, de 1961 . Em 1979, a Serra foi transformada em parque nacional e, em 1991, foi reconhecida como Patrimônio Mundial por seu valor cultural. Em 1993, foi inscrita no Livro do Tombo Arqueológico, Etnográfico e Paisagístico do IPHAN. A múltipla proteção é um acontecimento de interesse para o estudo da paisagem e de sua importância na política de preservação do meio ambiente e do patrimônio cultural.

A partir de pesquisa bibliográfica e de diversas fontes, apresentaremos a história, as mudanças físicas e algumas percepções da paisagem observadas no contexto da patrimonialização da Serra da Capivara. E assim, tentaremos responder à seguinte questão: o que muda com a criação do Parque, ou seja, na percepção e no próprio lugar?

Na década de 1970, a chegada dos pesquisadores na região sudeste do Piauí foi um marco de grandes transformações na paisagem da Serra da Capivara. O contato entre os habitantes, as instituições científicas e preservacionistas brasileiras e estrangeiras e o poder local produziu e revelou os conflitos e interdependência de interesses e induziu transformações mútuas de todos os envolvidos. 0 espaço como disputa, "cooperação e conflito" caracteriza a Serra (MOREIRA, HESPANHOL, 2007, p. 58).

O estudo das abordagens da paisagem na discussão sobre o PARNA SC e as percepções do lugar, antes e depois de sua criação como unidade de conservação, são os temas da pesquisa. A patrimonialização sobressai como nosso primeiro critério de abordagem dessa paisagem, indissociável dos sítios arqueológicos.

Para Collot (2013, p. 18), a paisagem é uma parcela de uma região que se oferece a um observador, um espaço percebido por meio de um ponto de vista. A noção de paisagem, como "o produto do encontro entre o mundo e um ponto de vista", está inserida em uma relação complexa de três componentes - local, olhar e imagem. As teorias da paisagem trataram de forma desigual esses componentes, dando ênfase ora ao local, ora à imagem, negligenciando o olhar. É na percepção que o fenômeno da paisagem possibilita um movimento de nosso interior para o mundo exterior e lhe dá sentido, experimenta a alteridade e constitui nossa subjetividade. É a "[...] mediação entre o mundo das coisas e o da subjetividade humana" (BERQUE, 1995, p. 22 apud COLLOT, 2013, p. 27).

Em 1992, a Convenção do Patrimônio Mundial da Unesco incorporou a noção de paisagem cultural como categoria de proteção. Em 2000, a Convenção Europeia da Paisagem (CEP) incluiu a paisagem como política pública com o objetivo da promoção da qualidade de vida dos cidadãos europeus. Em 2009, o Iphan instituiu a Chancela da Paisagem Cultural Brasileira, influenciado por essas normativas internacionais, com o objetivo de integrar as categorias de patrimônio, natureza e cultura. Nesse instrumento, a paisagem cultural é definida como "uma porção peculiar do território nacional, representativa do processo de interação do homem com o meio natural, à qual a vida e a ciência humana imprimiram marcas ou atribuíram valores" (IPHAN, 2009, p. 35).

\section{História e Percepções do Parna SC (sÉc. XIX-XXI)}

$\mathrm{Na}$ Geografia Humanística, lugar é considerado produto da experiência humana (TUAN, 1983); na dialética marxista, é entendido como espaço de singularidade, com características históricas e culturais decorrentes do processo de sua formação e que pode também ser expressão de globalidade (LEITE, 1998; COSGROVE, 1998; SANTOS, 2006, 2014).

A partir do século XIX, as áreas de caatinga da região da Serra Branca, hoje pertencentes ao PARNA SC, seus povos e formas de organização social sofrem mudanças na constituição do mercado mundial da borracha. No final do século XIX, após violento e predominante processo mortal de expulsão dos povos originários, essas áreas são ocupadas por exploradores da maniçoba (OLIVEIRA, 2001). Nas chapadas da região, a espécie era abundante e a exploração dos maniçobais nativos se torna possível devido à valorização econômica da borracha e do aprimoramento de suas técnicas de extração. 
A década de 1960 marca o final da exploração do látex da maniçoba no Piauí. A desvalorização da borracha no mercado mundial extingue a principal fonte de renda de seus habitantes. Pouco a pouco, os moradores da Serra Branca foram se mudando para os povoados e cidades vizinhas: Zabelê, Coronel José Dias e São Raimundo Nonato (Figura 01).

Na década seguinte, a descoberta das pinturas rupestres e a criação do PARNA SC transformam profundamente a vida do homem no sudeste do Piauí. No início dos anos 1970, a chegada da arqueóloga Niède Guidon àquele local foi provocada pelo interesse científico em fotos de pinturas rupestres que lhe foram apresentadas no Museu Paulista, em 1963. E assim, por meio de contato com o prefeito da cidade de São Raimundo Nonato, a de maior influência na região, pôde observar a singularidade das pinturas da Serra da Capivara (Figura 02), diferentes de tudo que Niède conhecia até então.
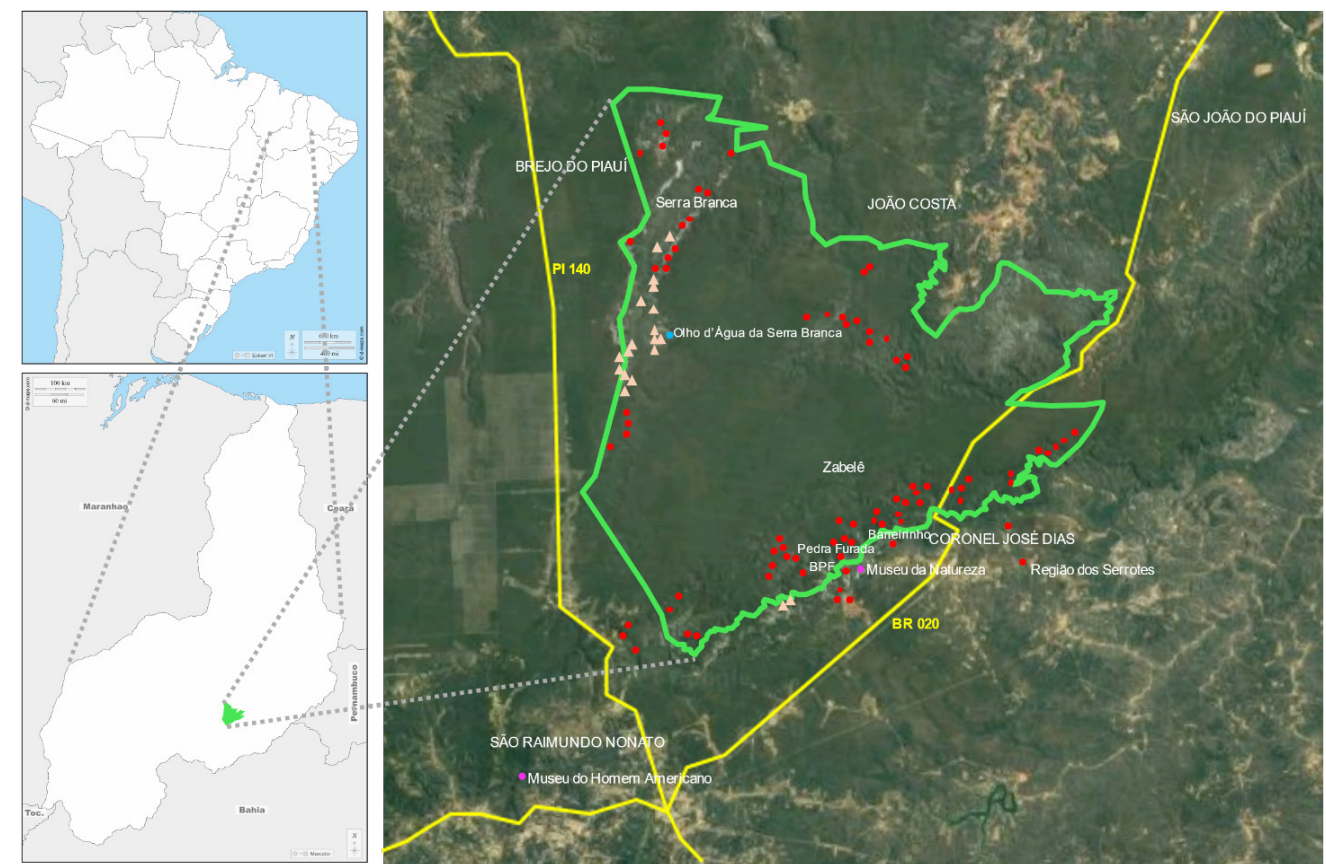

legenda

- sítio arqueológico sítio arqueológico utilizado como
moradia pelos maniçobeiros olho ơágua

- Parque Naciou
Museu

Museu
MUNICIPIO

MUNICIPIO
RODOVIA

estrada vicinal
Figura 01 - Localização do PARNA SC no sudeste do Piauí.

Fonte: Composição de maio de 2021 baseada em mapa da FUMDHAM (2014) sobre as bases cartográficas: -Google Maps, escala 1:10000 (2021).

Disponível em: <https://www.google.com.br/maps/place/ Parque+Nacional+da+Serra+da+Capivara/@-8.6472786 $42.778156,103438 \mathrm{~m} /$ data $=! 3 \mathrm{~m} 1$ ! $1 \mathrm{e} 3 ! 4 \mathrm{~m} 5$ ! $3 \mathrm{~m} 4 ! 1 \mathrm{~s} 0 \times 779 \mathrm{~d}$ $70 f 30299457 \cdot 0 \times 63 \mathrm{~d} 343 \mathrm{eb} 51 \mathrm{fea} 88 \mathrm{f} ! 8 \mathrm{~m} 2 ! 3 \mathrm{~d}-8.6952778 ! 4 \mathrm{~d}$ $42.5862674 ! 5 \mathrm{~m} 1 ! 1 \mathrm{e} 4 ? \mathrm{hl}=$ pt-BR\&authuser $=0>$ Acesso em: 30 mai.2021;

-D-maps, escalas 1:600000 e 1:100000 (2021). Disponível em:<https://d-maps.com/index.php?lang=pt $>$ Acesso em: 30 mai. 2021. 

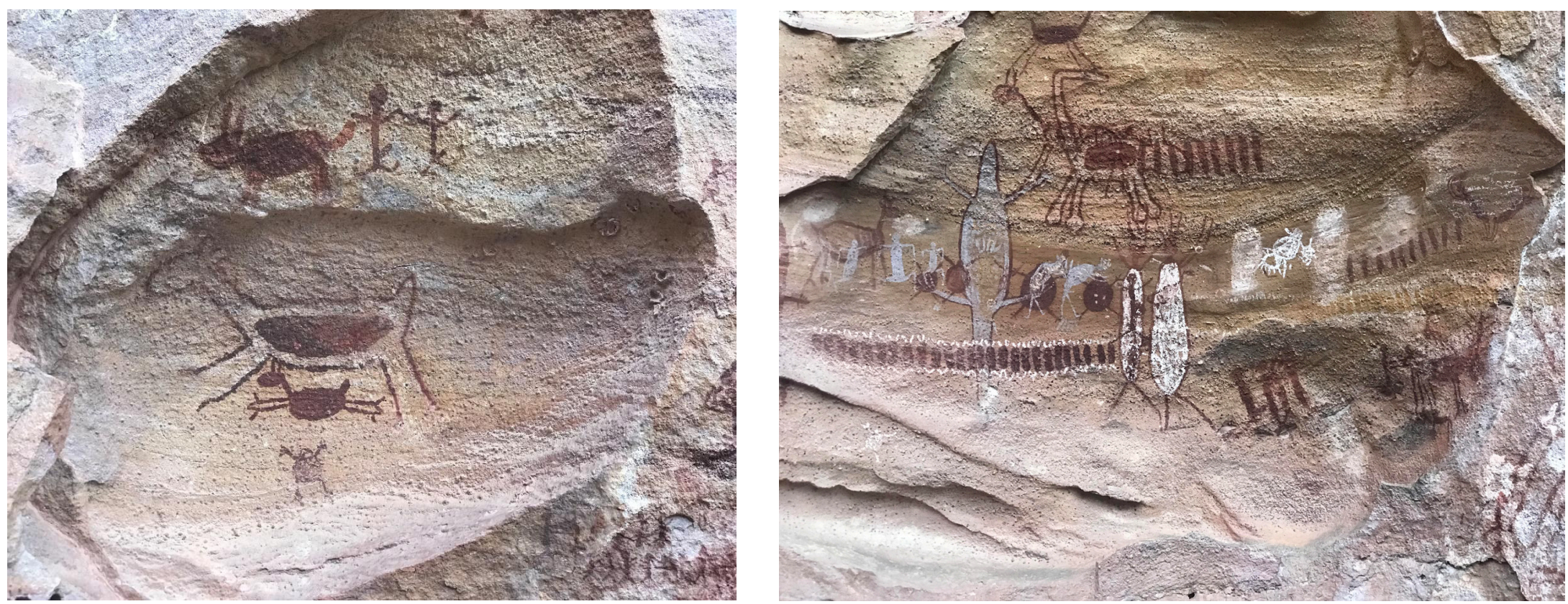

Figura 02 - Pinturas rupestres em nichos do Boqueirão da Pedra Furada (BPF-PARNA SC), apresentando variedade técnica, temática e policromia. A primeira imagem do cervídeo com filhote se tornou símbolo do parque.

Fotos: Diva Figueiredo, 2018.

Após contato com os registros fotográficos dessas pinturas, a arqueóloga conseguiu organizar junto ao Governo da França e à Universidade de São Paulo (USP), a formação de uma equipe dentro da Missão Franco-Brasileira para realizar os primeiros trabalhos de pesquisa no sudeste do Piauí. Além de Niède, que era vinculada profissionalmente à École des Hautes Études en Sciences Sociales em Paris, pela qual se aposentou em 2000, participaram das primeiras prospecções Silvia Maranca e Águeda Vilhena de Morais, da USP (BORGES; SANTANA, 2015). A Missão Franco-Brasileira foi interrompida pela aposentadoria de Niède Guidon e retornou em 2009 sob a responsabilidade de Eric Böeda, da Université de Paris $X$ Nanterre, França.

A arqueóloga e o prefeito de São Raimundo Nonato registraram o primeiro contato com as pinturas da Serra da Capivara em variadas entrevistas concedidas a pesquisadores, repórteres e depoimentos em documentários (FOGAÇA, 2013). O prefeito Gaspar Dias Ferreira referiu-se às pinturas rupestres como as "pinturas dos índios":

"[...] e um dia recebi um memorando do Museu Paulista. E nós estávamos falando sobre turismo, pontos turísticos da região, se aqui existia algum. E nós aqui na época discutindo: rapaz, vamos mandar para São Paulo essas pinturas dos índios, que isso é novidade! [...] E fiz uma carta para São Paulo, lá para o endereço que eles me deram, dizendo que era uma serra muito bonita, que todo mundo que passava admirava e que tinha essas pinturas que a gente chamava "pintura dos índios" (FOGAÇA, 2013, 16: 39 min., grifos nossos). 
As palavras do prefeito acentuam a beleza da paisagem e reafirmam uma percepção comum das pessoas que por ali passavam. No entanto, as "pinturas dos índios" são descritas com distanciamento, como coisa produzida pelo "outro" e consideradas exotismo e novidade a ser exibida aos de fora do lugar.

No final do século XVIII, no diário escrito por Antônio do Rego Castelo Branco guardado no Instituto Histórico e Geográfico Brasileiro (IHGB), encontramos o primeiro registro escrito dessas pinturas indígenas relatadas pelos soldados como antigas e que "representavam 'pássaros, onças, ratos e algumas desonestas"' (OLIVEIRA; NEGREIROS; ASSIS, 2014, p. 810). O julgamento moral das figurações, cujas cenas de sexo são frequentes, se coaduna com a visão católica do colonizador e a presença dos jesuítas no sertão do Piauí, a garantir o domínio dos valores cristãos, da catequese e da disciplina ocidental infligida aos gentios (Figura 03).
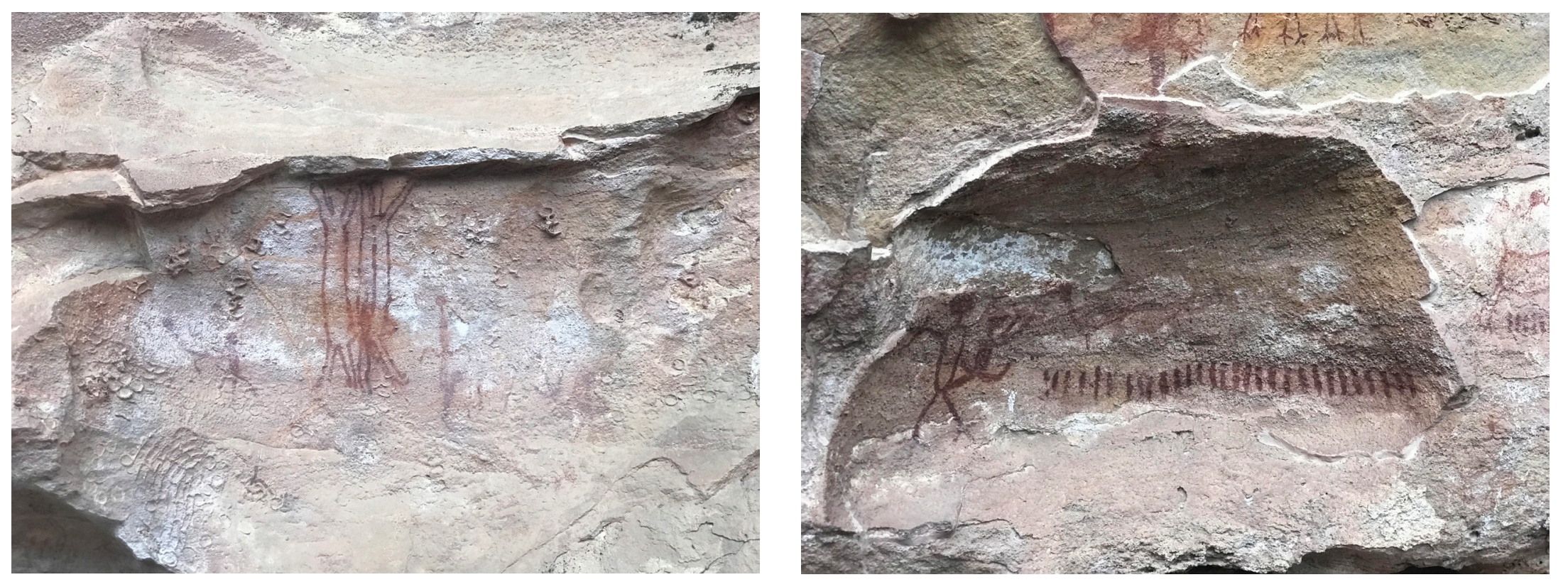

Figura 03 - Pinturas rupestres mostrando cenas de sexo parcialmente encobertas por ninhos de vespas e depósitos salinos (BPF-PARNA SC). Fotos: Diva Figueiredo, 2018

A convivência anterior à criação do Parque e a percepção que as pessoas do lugar tinham da paisagem podem ser observadas em algumas falas de antigos moradores da zona rural. Os povos originários também são conhecidos por eles como "caboclos bravos", conforme depoimento de morador do Zabelê, Z. L., de 95 anos, em entrevista a Godoi (1993). "E aí o que é certo, é que esta beirada de serra era cheia de índio nesse tempo. Índio quer dizer que é caboclo brabo, você sabe, os índio" (GODOI, 1993, p. 63). A percepção sobre a "pintura dos índios" se destaca na entrevista de Nilson Parentes a Borges e Santana (2015) no Novo Zabelê, em 09/2013:

"[...] as pinturas não eram nem todo mundo que conhecia, e quando eu era da idade de oito anos a dez anos eu gostava de andar mais meu avô nas pedras, aí eu via aquelas pinturas, aí eu perguntava: vô e o que é isso? Ele disse - isso aqui? Isso aí foram os índios que fizeram, aí 
as pinturas traduzindo era dos índios, então eu achava muito bonito e toda toca que eu chegava, eu ia olhar se os índios tinham andado, tinham escrito aquilo ali, então tomei conhecimento daquilo, daquelas pinturas, desde menino, então na região que eu andava tinha muitas, então eu conheci várias e várias tocas com aquelas pinturas" (BORGES; SANTANA, 2015, p. 117).

A caatinga é explorada à exaustão o que coloca em risco de extinção espécies da fauna, da flora e provoca a destruição de vestígios arqueológicos. A diminuição dos predadores naturais dos cupins, vespas e formigas fizeram-nos proliferar, causando destruição das pinturas rupestres (Figura 03) e impacto negativo sobre a flora. Para os pesquisadores da Missão Franco-Brasileira, as atividades agrícolas, principalmente as queimadas costumazes para limpeza dos terrenos e a caça sistemática, eram ameaças aos ecossistemas regionais e de destruição da arte rupestre. Esse contexto desencadeou o pedido da arqueóloga Niède Guidon feito por carta ao governador do Piauí:

"[...] seria impensável proibir essas queimadas, mas talvez a solução que o governo do Piauí conseguisse junto ao Governo Federal que toda essa região, incluindo zonas dos Municípios de São Raimundo Nonato, São João do Piauí, Canto do Buriti e Caracol, fosse transformada em Parque Nacional" (BORGES; SANTANA, 2015, p. 113).

De acordo com Guidon (2014), o objetivo da criação do PARNA SC foi proteger a maior concentração de sítios pré-históricos brasileira por meio de instrumentos jurídicos adequados. Em 1979, o decreto de sua criação delimitou apenas 100.764,19 hectares dos municípios de João Costa, Coronel José Dias, São Raimundo Nonato e Brejo do Piauí. Na época, a proposta dos pesquisadores era a criação de um parque com 130.000 hectares na Serra da Capivara, 500.000 hectares na Serra das Confusões e uma área de ligação entre as duas serras formando um corredor ecológico (PESSIS; CISNEIROS; MUTZENBERG, 2018). A constituição desse mosaico de duas áreas estritamente protegidas, intercaladas por uma área de uso controlado, é considerada pelos ambientalistas a melhor alternativa para a conservação da diversidade biológica e o manejo dos recursos naturais do bioma caatinga dos dois parques. Em 1990, a criação por decreto de 35.000 hectares de Áreas de Preservação Permanente (APP) justapostas à delimitação anterior amplia a área protegida (IBAMA, 2019).

A criação do parque permanece no papel por muitos anos e a ausência do Estado como agente fiscalizador provoca maior degradação da paisagem. Em 1986, essa situação levou os pesquisadores de diversas formações ligados a instituições brasileiras e estrangeiras atuantes na região a instituir a Fundação Museu do Homem Americano (FUMDHAM), com o objetivo de preservar o acervo cultural e natural da área protegida. Desde então, a FUMDHAM celebra reiterados contratos de cogestão do parque com o IBAMA e o ICMBIO (ICMBIO, 2019). Estabelece também diversas outras parcerias com o mesmo objetivo, inclusive com o IPHAN. Alguns dos membros da FUMDHAM participaram dos conselhos editoriais de 20 edições de sua revista científica FUMDHAMentos, entre 1996 e 2020, além de sua fundadora, Niède Guidon. Entre eles estão Adauto J. G. de Araújo - Fundação Oswaldo Cruz (FIOCRUZ); Anne-Marie Pessis - Universidade Federal de Pernambuco (UFPE); Claude Guérrin - Centre des Sciences de la Terre, Université de Lyon 1 France; Gabriela Martin Ávila - Fundação Seridó e UFPE; Marcia Chame - FIOCRUZ-RJ; Maria Conceição Soares Meneses Lage - Universidade Federal do Piauí (UFPI); Martine Faure - Laboratoire d'Anthropologie et d'Ethnologie, Université de Lyon 2; Silvia Maranca - Museu de Arqueologia e Etnologia da Universidade de São Paulo (USP).

Em 1984, o IBAMA assina convênio com a FUMDHAM para a demarcação do Parque. E nesse momento, percebe o equívoco de se ter considerado a área delimitada como livre de ocupação humana (IPHAN, 1992). Consequentemente, ocorre uma ruptura na vida de gerações de famílias do povoado Zabelê, dedicadas à exploração da maniçoba a partir do final do século XIX até a década de 1960. A desapropriação, iniciada em 1988, gera uma situação fundiária complexa, provocada por dados discrepantes, demora no processo de indenização, baixos valores recebidos e pelo fato de nem todos receberem indenizações. Em 1997, é criado o assentamento Novo 
Zabelê, a 10 km de São Raimundo Nonato, para abrigar pessoas da comunidade desapropriada (BORGES, SANTANA, 2015).

O interesse científico despertado pelas pinturas rupestres produz visibilidade para a paisagem de grande beleza cênica, diversidade ecológica e rico acervo arqueológico. O encontro entre a planície pré-cambriana da depressão periférica do São Francisco e o planalto da bacia sedimentar Maranhão-Piauí produziu múltiplas formações geológicas, ecossistemas e recursos naturais. No Devoniano, a região era mar, cujo fundo foi soerguido por um movimento tectônico ocorrido na era Mezozoica, dando origem ao relevo. A ação dos ventos e da água abundante durante clima úmido existente até a 10000 anos B.P. modificou o relevo ao longo do tempo. As chapadas são recortadas por cânions profundos, pa- redões ruiniformes, aglomerados de seixos e afloramentos rochosos, onde os povos pré-históricos e a fauna encontraram abrigo. No transcorrer das estações, o colorido da caatinga se transforma do verde para o avermelhado e o cinza e lilás da "Mata Branca", como era conhecida pelos indígenas (ICMBIO, 2019) (Figuras 04, 05 e 06).

Entretanto, a visibilidade obtida também evidencia o contraste entre os recursos destinados ao Parque e a vida precária da população do interior, pressionada pelos escassos meios de sobrevivência. A alternativa de exploração dos recursos do ambiente entra em conflito com os pressupostos, práticas e instrumentos legais de preservação da paisagem e do patrimônio arqueológico.

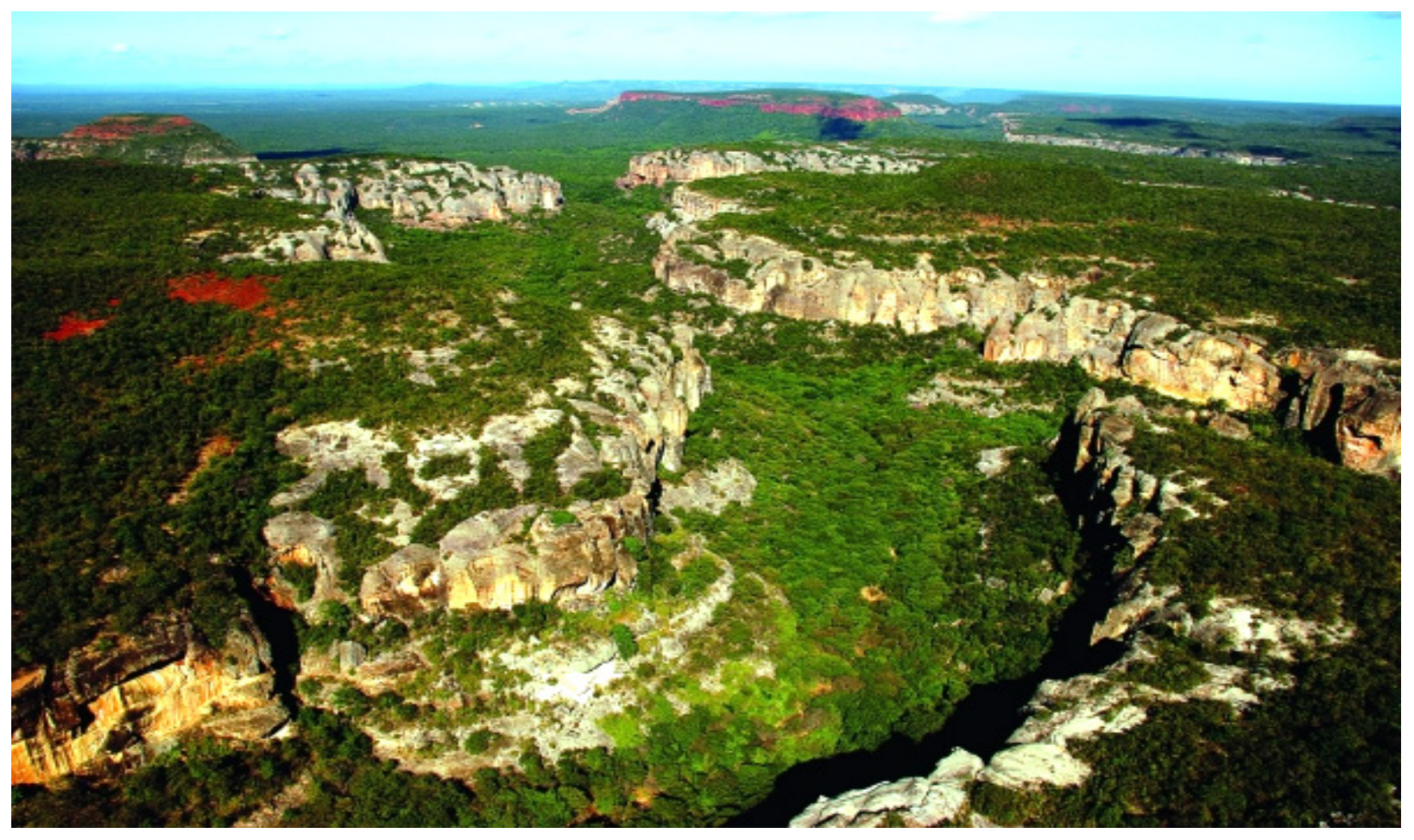

Figura 04 - Vista aérea das chapadas, dos cânions, das planícies e da vegetação do PARNA SC, no período chuvoso.

Foto: FUMDHAM, s. d

Disponível em: < http://fumdham. org.br/wp-content/uploads/2018/08/ fumdham-parque-nacional-serra-dacapivara-parque-nacional-serra-dacapivara-600x402.jpg.> Acesso em: 15 maio 2021. 


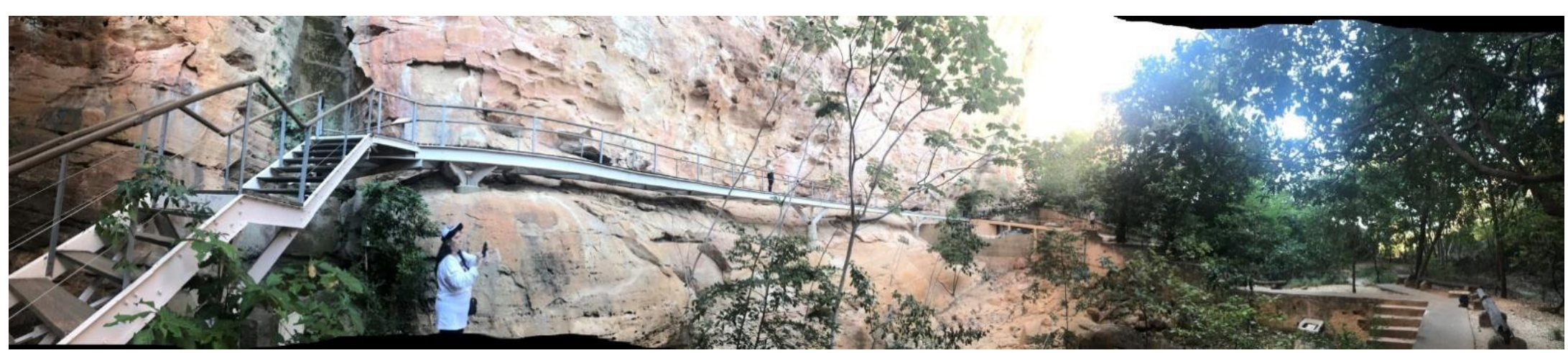

Figura 05 - Vista panorâmica do sítio BPF, famoso pela concentração de pinturas elaboradas ao longo de milênios de ocupação do sítio e pelas datações antigas dos vestígios de fogueiras pré-históricas.

Foto: Diva Figueiredo, 2018
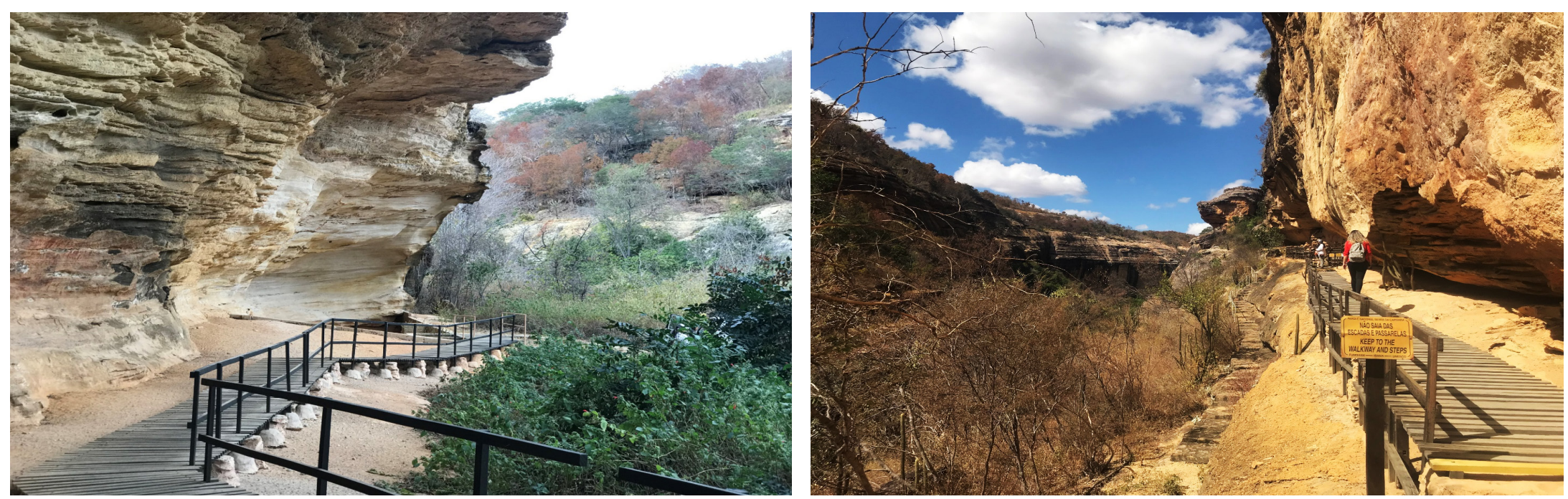

Figura 06 - Vistas de diferentes abrigos preparados para visitação e da variedade das cores da caatinga.

Fotos: Diva Figueiredo, 2018. 
Os pesquisadores percebem a necessidade de integrar as circunstâncias sociais e econômicas do meio rural com os estudos ambientais e arqueológicos. A vocação para o turismo é apontada pelo Banco Interamericano, conforme Guidon em documentário da Unesco/Brasil (FOGAÇA, 2013) e previsto no plano de manejo elaborado pela FUMDHAM, em 1991. Muitas ações foram desenvolvidas com o objetivo de preservar o patrimônio cultural, o meio ambiente e desenvolver o turismo, associadas à promoção dos trabalhadores locais. Algumas não perduram, mas formam uma geração de pessoas que trabalha com o PARNA SC. Outras respondem pelo sustento de famílias até hoje. Entre elas se destacam (MAIOR,
2016): Núcleos de Apoio às Comunidades (1989-2001); Cerâmica Artesanal Serra da Capivara (1992-2001-Atual); Desenvolvimento da Apicultura Sustentável e Familiar (1993-Atual); Pró-Arte FUMDHAM (2002-2012); Cursos de Arqueologia e Ciências da Natureza no campus da UNIVASF de São Raimundo Nonato (2004-Atual). As parcerias diversas, algumas viabilizadas pela Lei Rouanet, permitem dotar o PARNA SC de uma ampla infraestrutura com a construção e manutenção de centro de visitantes, guaritas, estradas e trilhas, passarelas, instalações e sítios adaptados para deficientes, conservação das pinturas etc. (Figuras 07 e 08).
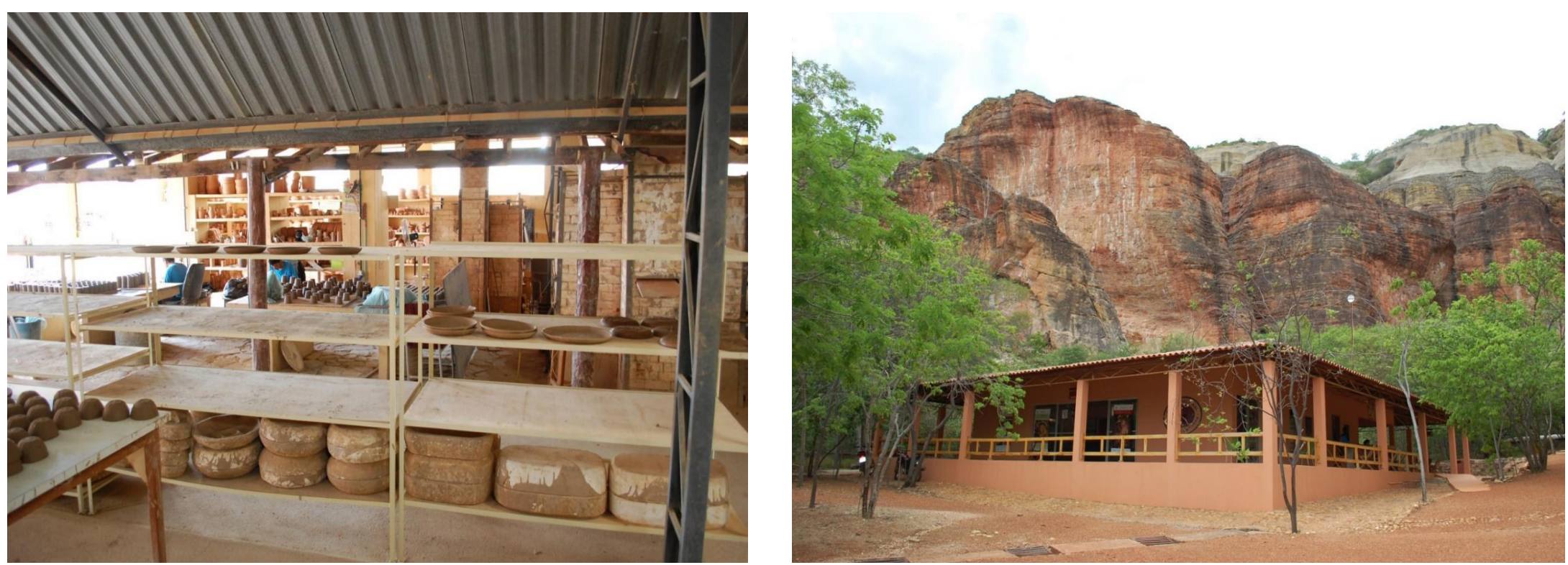

Figura 07 - Centro de Visitantes na entrada do BPF e da Cerâmica Artesanal da Serra da Capivara. Fotos: Diva Figueiredo, 2018 e 2019. 


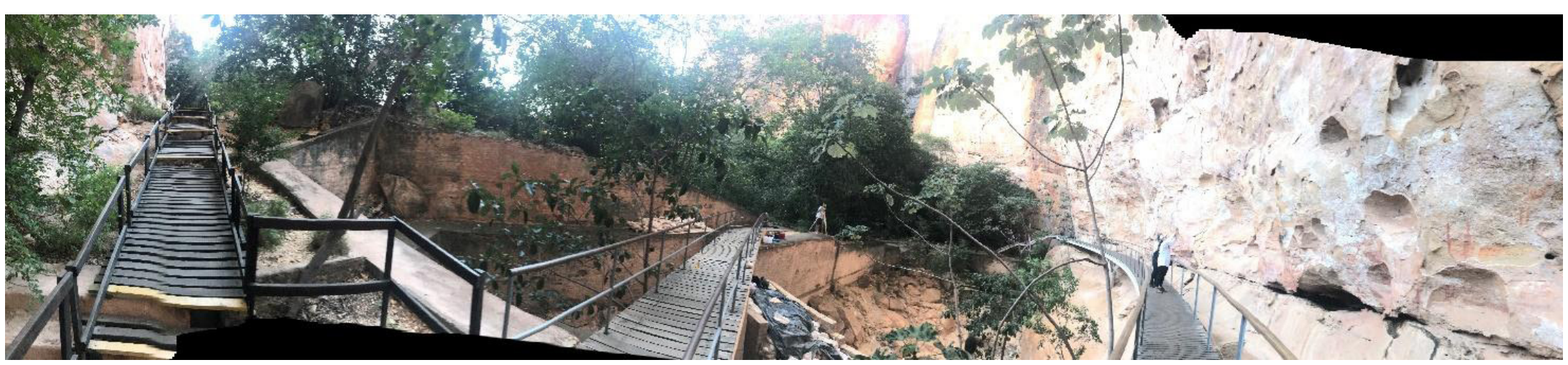

Figura 08 - Vista panorâmica do BPF mostrando o acesso para pessoas com deficiência no centro da imagem. Foto: Diva Figueiredo, 2018.

Em São Raimundo Nonato, desde 1990, o Museu do Homem Americano, justaposto a um centro cultural, expõe e guarda o acervo arqueológico da região. A partir de 2004, cursos de Arqueologia e Ciências da Natureza pela Universidade do Vale do São Francisco (UNIVASF) foram criados no campus que se instala nas proximidades desses dois equipamentos e, constituem oportunidades de formação e de trabalho para as pessoas do lugar. No município de Coronel José Dias, em 2018, foi inaugurado o Museu da Natureza, focado na criação do universo e nos impactos do clima na fauna e flora (Figuras 09 e 10). Um ano aberto, esse museu revelou-se sucesso de público comparado ao parque e ao Museu do Homem Americano, com aproximadamente 45.000 visitantes.

A gestão compartilhada do Parque entre IBAMA e FUMDHAM é elogiada na $27^{\text {a }}$ Sessão do Comitê do Patrimônio Mundial, em 10/12/2003, "por transformar o Parque Nacional Serra da Capivara ao longo de uma década a partir de uma 'parque de papel' em uma das áreas protegidas mais bem gerenciadas da América Latina" (UNESCO, 2003, p. 108, tradução nossa). O Comitê reitera o reconhecimento do parque como patrimônio cultural (1992), mas novamente rejeita o reconhecimento como patrimônio natural. A candidatura, desta vez, usa a estratégia do Sistema Nacional de Unidades de Conservação (SNUC), recém instituído em 2000, de criar um mosaico de unidades de conservação diferenciadas. A decisão negativa deve-se à mínima estrutura do Parque Nacional da Serra das Confusões, criado em 1998, e à inexistência do corredor ecológico Capivara-Confusões, só oficializado em mosaico em 2005.

A grandiosidade dos recursos culturais e naturais do Parque e os seus projetos sociais o colocam sempre no centro das atenções da mídia brasileira. As reportagens nacionais, com regular frequência, são disparadas por falta de recursos para a manutenção da ampla infraestrutura criada para as pesquisas científicas, a preservação e a visitação do PARNA SC. Niède Guidon responde a uma repórter sobre o que a motivava a realizar esse trabalho de tantos anos, apesar da sua frequente ameaça de abandoná-lo, frente às condições adversas do meio, da falta de recursos e das ameaças de morte que sofreu:

"Ir para o parque é uma das coisas mais belas que eu já tive na minha vida. É tão bonito quanto passear por Paris. Porque realmente é um monumento fantástico. Fiz isto de uma maneira egoísta, para me dar prazer" (RODA VIVA, 2016).

Como observa Tuan (1980), as mais intensas experiências estéticas são descobertas surpreendentes da beleza. No primeiro contato com a região, o impacto que a natureza e a arte rupestre provo- 

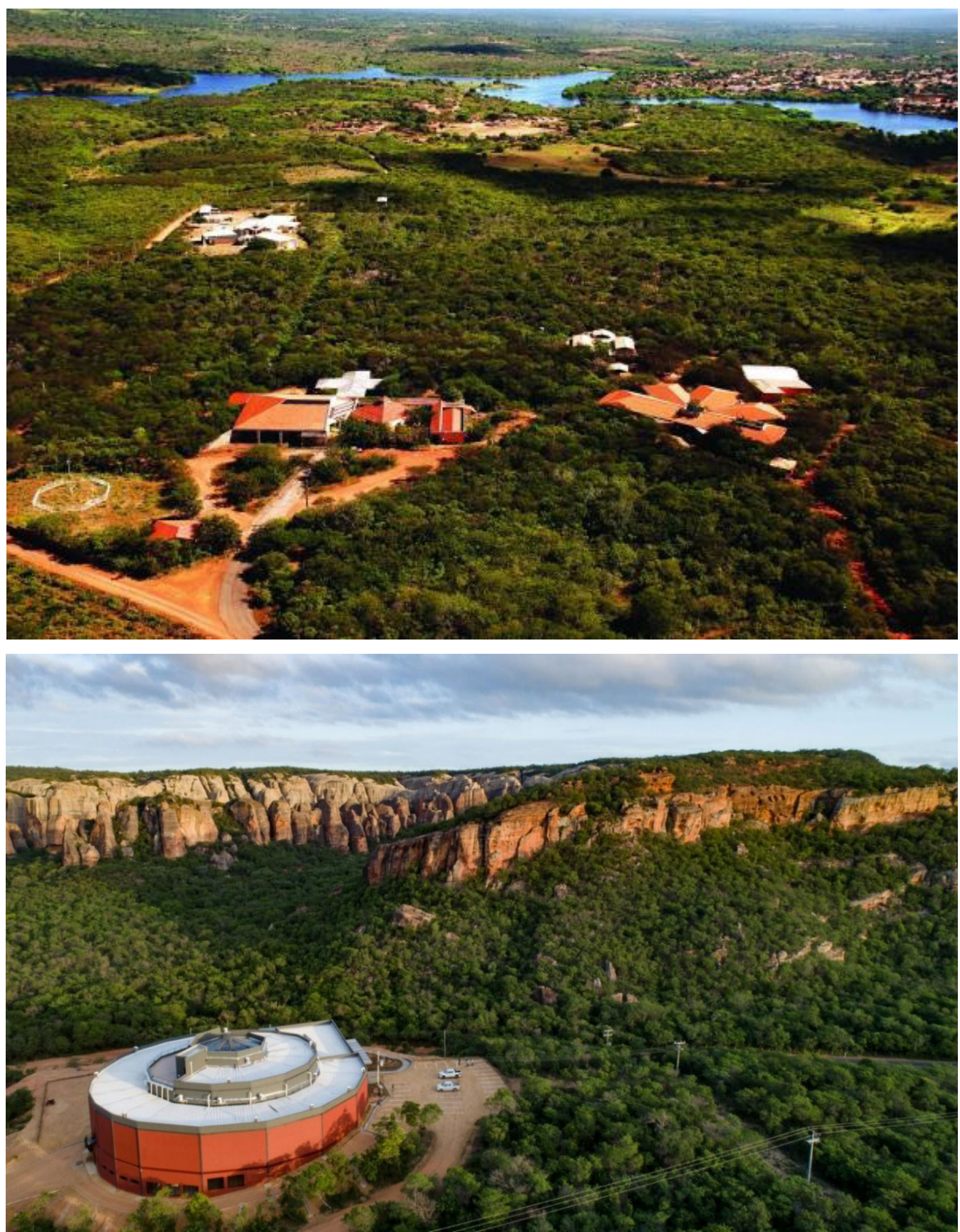

Figura 09 - Vista aérea de São Raimundo Nonato. No primeiro plano à esquerda o Museu do Homem Americano e à direita o Centro Cultural Sérgio Motta. Em segundo plano, campus da UNIVASF, depois o rio Piauí e parte de São Raimundo Nonato.

Foto: FUMDHAM (s.d.).

Disponível em: <http://fumdham.org.br/wp-content/ uploads/2018/08/fumdham-v2-museu-do-homemamericano-fumdham.jpeg >

Acesso em 19 mai. 2021
Figura 10 - Vista aérea do Museu da Natureza, em Coronel José Dias.

Foto: FUMDHAM (s.d.).

Disponível em: <http://fumdham.org.br/midias/midiasfotos/\# >

Acesso em 24 ago. 2020. 
caram na pesquisadora foi determinante na patrimonialização da Serra da Capivara. O encantamento com a beleza da paisagem e a concentração dos registros rupestres impacta quem conhece o PARNA SC pela primeira vez.

A patrimonialização da Serra também pode ser lida no nível discursivo com o aporte de Foucault (2015). Para o autor, a emergência histórica de um acontecimento discursivo ocorre em um jogo de relações com outros sistemas exteriores, que teria permanecido invisível, embora não seja secreto ou novo.

\section{0 maniçobeiro na Paisagem da Serra Branca}

A paisagem da região semiárida do sudeste do Piauí é percorrida pelos médicos Belisário Pena e Artur Neiva, em 1912. Na sua percepção, destacam-se a seca e a destruição da vegetação nativa pela prática do fogo, tecnologia herdada pelo sertanejo dos antigos habitantes:
Quando o Brasil foi descoberto, certamente aquelas zonas vinham sofrendo já a influência das forças naturais da dessecação progressiva: a civilização invadiu aqueles sertões, abrasando as matas. Hoje a destruição continua sempre em maior escala; o sertanejo inconsciente está preparando o deserto; é esta a verdade. - Os aborígenes que habitavam no Brasil antes do descobrimento só conheciam um único meio de amanhar a terra e que era o fogo; deles, os invasores não só herdaram a técnica, como ainda perpetuaram a tecnologia absorvida pelo vernáculo, como se verifica pelos vocábulos 'capueira, caiçava e coivara' (PENA; NEIVA, 1916, p. 83).

O texto acima faz parte dos relatos sobre o uso do fogo pelos povos originários que, segundo Falleiro, Santana e Berni (2016), acentua uma visão preconceituosa da prática indígena, baseada no olhar científico do colonizador e que permanece inalterada diante do fato que as terras indígenas são as mais conservadas do país e onde há menores índices de desmatamento (FALLEIRO; SANTANA; BERNI, 2016, p. 90).
A percepção da paisagem dos médicos contrasta com a do poeta/ maniçobeiro, nascido no povoado Gameleira, em São Raimundo Nonato, em 1886: uma percepção orientada pelos laços afetivos e históricos que, segundo Tuan (1980, p. 110), faz da apreciação da paisagem "quando mesclada com lembranças de incidentes humanos", mais pessoal e duradoura.
Para mostrar os encantos
Que nossa vista fascina
Se vê por todos os lados Rochedo e vasta colina,
Parece que a natureza
Esmerou toda beleza
Formando esta obra eterna
Além da bela paisagem
Existe nesta paragem
Rochedo, gruta e caverna (OLIVEIRA, 2014, p. 47).

A percepção do poeta/maniçobeiro é orientada pelo sentido de pertencimento do indivíduo pelo local do trabalho, de moradia, da vida cotidiana, que dificilmente se adquire pela simples passagem por uma localidade. Ela resulta no sentido de lugar forjado pela experiência, individual ou coletiva, desde que compartilhados os mesmos costumes. Segundo Tuan (1983, p. 163), "as experiências dentro de um grupo humano se sobrepõem o suficiente para que vínculos individuais não pareçam notórios e incompreensíveis para seus pares".

“[...] A percepção é enriquecida por todos os significados sociais. Uma paisagem tem a felicidade de nos apresentar uma naturalização do social e uma socialização da natureza" (SANSOT, 2009, p. 36 , tradução nossa). Ao habitar a caatinga, os maniçobeiros imprimem sua marca na paisagem da Serra Branca, como o fizeram os homens pré-históricos e indígenas que ali habitavam antes de sua expulsão, configurando um lugar significativo e persistente, como as cachoeiras em territórios indígenas estudadas por Almeida e Kater (2017). Os autores partem do pressuposto de que há uma matriz interpretativa que dota a cachoeira de significância para os povos originários, que considera, além de seus componentes físicos 
e ambientais, os componentes ideológicos, históricos, econômicos, territoriais e simbólicos (ALMEIDA; KARTER, 2017). E recorrem às noções de lugares significativos e lugares persistentes, tratados por Zedeño e Browser (2009).

As paisagens tornam-se lugares significativos, isto é, um espaço no qual as pessoas (inter)agem tanto com o meio ambiente quanto com o sobrenatural, sem que seja preciso modificá-lo, quando se reconhece a existência desse determinado local, individual e coletivamente, por meio das experiências e pelas memórias partilhadas pelo grupo, definindo assim sua significância. A longa duração no uso desse espaço o transforma, ainda que sejam alterados seus significados, em um lugar persistente (ALMEIDA; KATER, 2017, p. 42).
Na Serra Branca, os maniçobeiros, além de criarem o Povoado Zabelê, fazem uso das tocas pré-históricas ali existentes para construírem suas residências (Figuras 11 e 12). Em trânsito cotidiano entre o povoado, as tocas, os locais de trabalho nos carreiros da maniçoba, o olho d'água, traçam caminhos para procurar e comercializar a maniçoba, descansar ao final do dia, participar de atividades sociais e religiosas.

Entre os carreiros, as serras e a chapada existem lugares significativos para os maniçobeiros, tanto como espaços coletivos quanto individuais. O Olho d'água da Serra Branca e a Toca do João Sabino são lugares sempre mencionados nas entrevistas com muito carinho e respeito (LANDIM, 2014, p. 106-107).

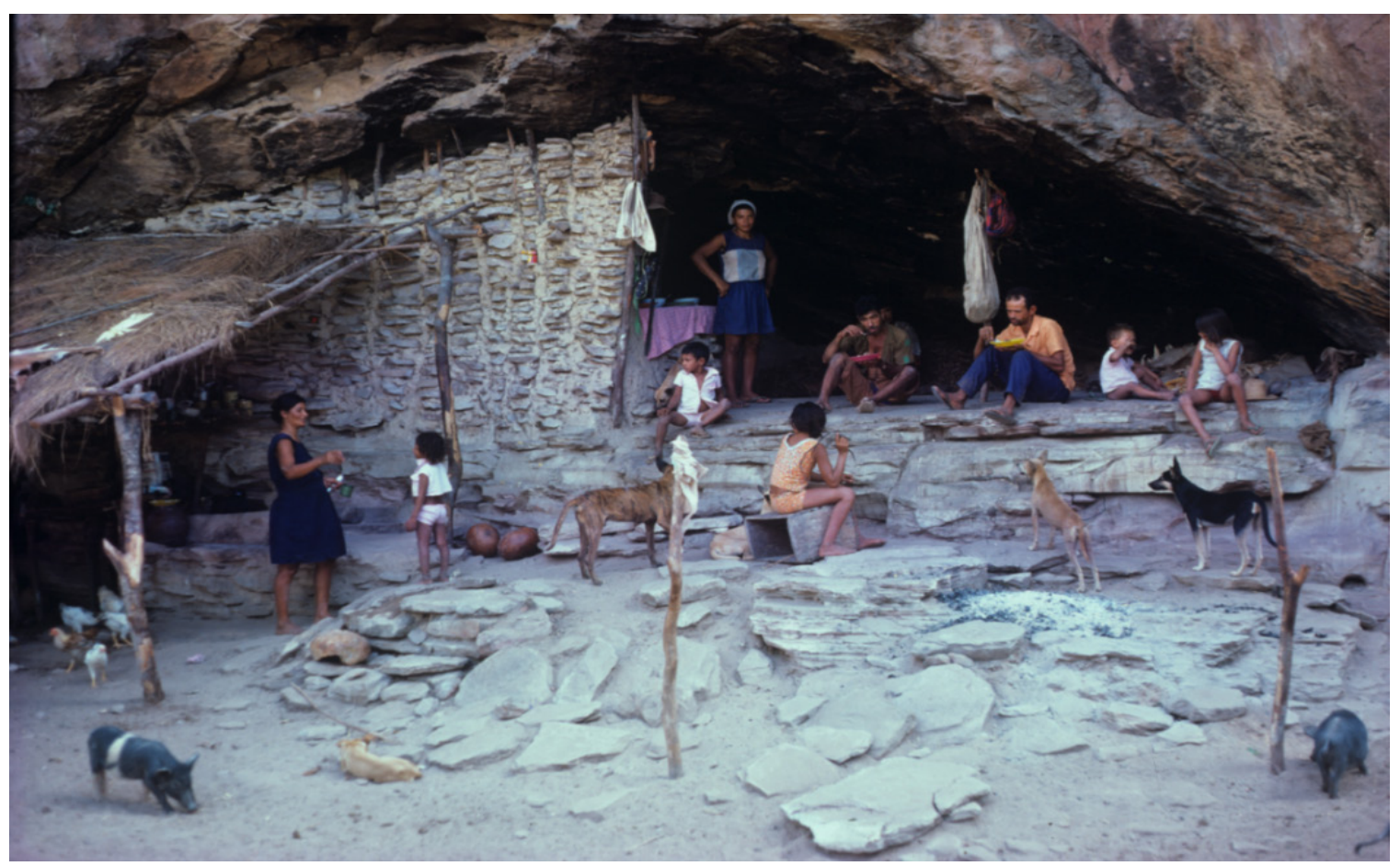

11 - Abrigo pré-histórico Toca do Juazeiro da Serra Branca (PARNA SC) usado por família de maniçobeiro até 1970 . A toca faz parte do circuito de visitação do parque. Foto: FUMDHAM (1978) 

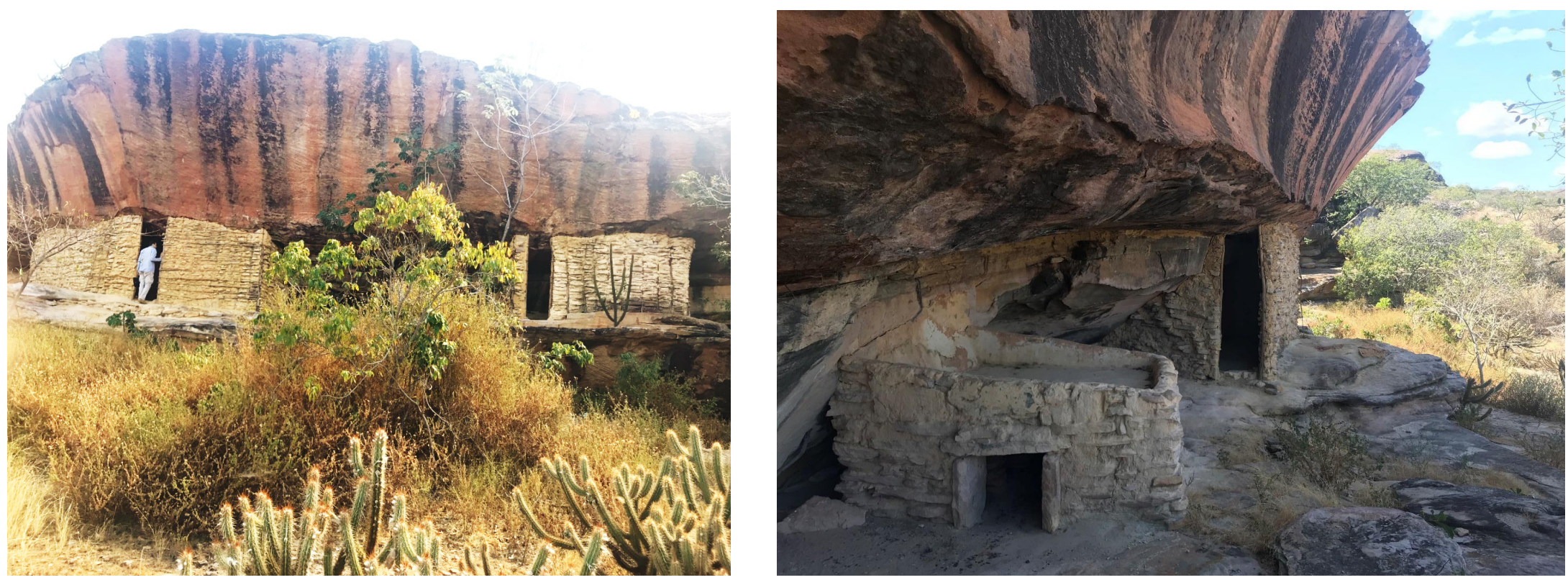

Figura 12 - Vistas das duas casas de taipa da Toca do João Sabino, da vegetação da caatinga nas imediações, do forno de farinhada e depósito. Fotos: Diva Figueiredo, 2018.

Conforme Seu Nôca, morador do Novo Zabelê, a toca do João Sabino (Figura 12) era o lugar das relações sociais com a Comunidade dos Maniçobeiros da Serra Branca. Ali se realizavam batizados e casamentos, quando, esporadicamente, era visitada por um padre que chegava montado em um burro. Era também o local da troca do látex da maniçoba com os barraquistas e das famosas festas de São João da Serra Branca que juntavam umas 200 pessoas (CÂMARA, 2019).

Landim (2014) explora a memória dos maniçobeiros e reclama da desconsideração do seu patrimônio cultural nos processos de reconhecimento da área da Serra da Capivara como Parque Nacional, Patrimônio da Humanidade e Patrimônio Cultural Brasileiro. Mas trata-se de um anacronismo exigir que as políticas públicas que protagonizam esses reconhecimentos entre as décadas de 1970 e
1990 considerem também esse patrimônio. Em primeiro lugar, a preocupação dos cientistas que pedem a criação do parque é de proteger da destruição os sítios arqueológicos, a fauna e a flora da região. Em segundo, o país vive à época uma ditadura militar, um contexto totalmente adverso a colocar em pauta a valorização de direitos sociais de populações minoritárias.

O mesmo se pode dizer sobre o título de Patrimônio da Humanidade, conquistado em 1991 e o tombamento em 1992, embora realizados depois da promulgação da Constituição de 1988, que amplia os direitos sociais das comunidades tradicionais e o próprio conceito de patrimônio. Quando ocorre a dupla proteção não há um conhecimento mais profundo sobre a vida dos maniçobeiros na região e tampouco se reivindica sua identidade, uma vez que a exploração da maniçoba havia se extinguido na década de 1960. Esse 
conhecimento se evidencia um pouco mais tarde, por meio da pesquisa de Oliveira (2001) sobre a vida desses habitantes que tiveram de sair do PARNA SC e/ou parar de extrair dele o seu sustento, através da caça, da extração de madeira e da prática de agricultura de subsistência. Somente mais tarde, o Estado brasileiro reconheceu a diversidade dos povos e comunidades tradicionais e seus direitos por meio do Decreto n 6040/2007.

A pesquisa de Oliveira (2001) é a primeira a evidenciar a identidade maniçobeira na ocupação histórica das áreas do PARNA SC, antes invisível frente à grande quantidade e qualidade dos vestígios pré -históricos que conquistam grande visibilidade nos meios científicos e na mídia de modo geral, notadamente pelo valor antropológico das pinturas rupestres, razão do título de patrimônio mundial.

A pesquisadora dos maniçobeiros do sudeste do Piauí, Ana Stela de Negreiros Oliveira, assinala que a criação da trilha interpretativa dos maniçobeiros no PARNA SC, baseada em sua pesquisa, tem fundamental importância na elevação da autoestima desses exploradores da caatinga:

Com isso, o maniçobeiro virou uma categoria social. Você fala com seu Nôca e descobre que agora ele frequentemente vai com alunos de escolas até Serra Branca. E outro dia a prefeitura resolveu homenagear várias categorias. E o representante do trabalhador de São Raimundo Nonato foi um maniçobeiro. Hoje eles são chamados para debater em universidades, ganharam voz, estão falando, melhorou até a autoestima deles (CÂMARA, 2019).

Reveladora nesse sentido é a resposta do maniçobeiro Nilson Parente dada a Landim (2014, p. 109), quando ela o questiona sobre o que achava das pesquisas sobre a maniçoba: "O que eu acho é que eu fazia isso aí por achar bonito e bom, e eles achavam que eu era um herói pra isso né? Mas, eu achava que eu num era ninguém, mas eles me deram valor e eu fiquei contente".

Cosgrove (1998) discorre sobre culturas dominantes e alternativas. Se as culturas dominantes ou hegemônicas se sobressaem às alternativas, a mudança da escala de observação pode subverter essa hierarquia. Foi o que ocorreu com a Serra da Capivara com o olhar dos arqueólogos sobre a cultura dos povos nativos muito antigos, Cultura alternativa até os anos 1970, a partir da criação do PARNA SC ela passa a cultura dominante.

Entre as culturas alternativas, o geógrafo inglês considera as residuais, as emergentes e as excluídas. A cultura residual cria a paisagem relíquia, exemplificada pelo complexo de pinturas rupestres da Serra da Capivara, que são pistas, mas de difícil recuperação do seu significado. A interpretação dos diversos conjuntos dessas pinturas depende do conhecimento da "linguagem" empregada, ou seja, dos símbolos e de seu significado na cultura que os produziu, desaparecida há milênios. Na verdade, a interpretação que fazemos revela também sobre nossas crenças e valores (COSGROVE, 1998).

No PARNA SC, particularmente na Serra Branca, a cultura dos maniçobeiros permanece muito tempo invisível para as políticas públicas e patrimoniais até ser valorizada pela pesquisa histórica publicada sob o título Catingueiros da Borracha (OLIVEIRA, 2001).

No Brasil, a partir da Constituição de 1988, os instrumentos legais e operacionais que refletem uma visão mais integrada de todas as categorias do patrimônio foram sendo adotados paulatinamente, à medida de sua demanda social e do fortalecimento do direito político das comunidades tradicionais, indígenas e quilombolas. Algumas conquistas são muito recentes. A política do patrimônio imaterial brasileiro, que visa salvaguardar costumes, saberes, lendas, rituais, línguas e tecnologias tradicionais e que almeja corrigir alguns efeitos da oposição natureza-cultura, é instituída alguns anos depois. Em 2000, surgiu o Registro do Patrimônio Imaterial e o Programa Nacional do Patrimônio Imaterial (BRASIL, 2000). Em 2010, foi a vez do Inventário Nacional da Diversidade Linguística (INDL), com a finalidade de estudar e reconhecer como patrimônio cultural as línguas faladas do Brasil (BRASIL, 2010). A Chancela da Paisagem Cultural Brasileira, inspirada no conceito de paisagem cultural da UNESCO, de 1992, e em concepções da Convenção Europeia da Paisagem, de 2001, é regulamentada em 2009 (IPHAN, 2009) e, mesmo assim, permanece sem operacionalidade até os dias atuais. 
Somente em 2015, por regulamento interministerial e após muito tempo ignorado nas consultas prévias de processos de licenciamentos ambientais de empreendimentos, o IPHAN e outros órgãos passam a ser oficialmente ouvidos como intervenientes. O IPHAN, por sua vez, estabelece em regulamento próprio as formas de sua participação e as restringe aos bens acautelados em âmbito federal. Assim, a concepção integrada, prevista no instrumento da Chancela da Paisagem Cultural Brasileira, poderá se tornar efetiva, figurando entre as categorias acauteladas no contexto do Licenciamento Ambiental.

\section{Considerações Finais}

Entre os ambientalistas, há um movimento que reconhece os direitos de as comunidades tradicionais se beneficiarem da conservação ambiental. Outro que utiliza a noção metafísica de natureza para defender a biodiversidade em si, afastada da presença humana. A noção de natureza intocada ainda é adotada por diversos pesquisadores. Ela credita à conservação tradicional das unidades de conservação integral, que permitem apenas os usos científico e turístico dentro dessas unidades, o retardo do colapso ecológico global (CALEGARE; HIGUCHI; BRUNO, 2014).

Pesquisadores da fauna no PARNA SC e seu entorno, que participaram do Plano de Manejo de 1991 pela FUMDHAM, revelam claramente posição favorável à conservação tradicional. Eles atribuem o aumento da população de várias espécies de animais sob ameaça de desaparecimento à fiscalização intensa e sistemática trazida pelo PARNA SC. E consideram positivo o desaparecimento de aves domésticas (Passer domesticus) nas antigas áreas exploradas pelos moradores do Zabelê, substituídas por áreas de vegetação mais fechada (OLMOS, BARBOSA, ANDRADE, 2014).

Olmos et al. (2001) consideram que há prova científica suficiente da perda de espécies decorrentes de exploração intensiva por "comunidades tradicionais" contemporâneas, principalmente pela caça de subsistência. "Muitas das generalizações sobre a relação harmoniosa das populações tradicionais com o meio ambiente carecem de provas" (OLMOS et al., 2001, p. 286). Para eles, é a baixa densidade populacional e a deficiência tecnológica que explicam a sustentabilidade na exploração de recursos naturais e não as tradições culturais de harmonia consciente com a natureza (OLMOS et al., 2001).

Argumentam, ademais, que há milhares de anos e no período précolonial, as populações indígenas mais numerosas teriam provocado grande degradação ambiental, dando razão a Diegues (2008) ao considerar a "natureza intocada" um mito. Defendem haver uma confusão entre o que são questões ambientais e "agendas políticas e demandas sociais" (OLMOS et al., 2001). É um ponto de vista que dissocia a ciência do seu contexto social e político. E que projeta o modelo do laboratório, das variáveis sob controle para fora dele.

Entre os pesquisadores, inclusive os reunidos na FUMDHAM, ainda permanecem noções divergentes da paisagem: ora se atribui aos povos pré-históricos da Serra Capivara e aos povos exterminados no contato com o colonizador uma relação harmoniosa com a natureza (PESSIS, 2013, GUIDON, 2014), ora se admite a sua participação na extinção da fauna de grande porte (OLMOS et al., 2001; PESSIS, MARTIN, GUIDON, 2014).

Ao nomear e separar o homem da natureza e inferir nessa operação um conflito inerente entre eles, a conservação tradicional considera as comunidades locais incapazes de estabelecer um manejo equilibrado do seu entorno (ARRUDA, 1999). Se há ou houve excessos em algumas formas de exploração, como o que ocorreu anteriormente com a Serra da Capivara, isso não pode ser eternizado. No modelo de gestão construído pela FUMDHAM em parceria com agências do Estado, elogiado pelo Comitê do Patrimônio Mundial em 2003, destacam-se dois aspectos essenciais. De um lado, a gestão se baseia na fiscalização intensiva e punitiva da unidade de conservação integral, defendida por Olmos et al. (2001), acompanhada por trabalhos de ótima qualidade na conservação e promoção do patrimônio cultural e da biodiversidade. De outro, está a aposta em uma mudança de mentalidade por meio da educação ambiental e patrimonial das gerações mais novas, além da promoção social, com ênfase na promoção do trabalho feminino como forma de sustento das famílias e de combate à violência de gênero. 
As conquistas sociais e econômicas desse modelo de patrimonialização da área beneficiaram as comunidades de Coronel José Dias e São Raimundo Nonato ao tempo em que se interrompeu um processo acelerado de destruição da biodiversidade e dos sítios arqueológicos. O custo alto dessas conquistas foi a forma de afastamento da população que vivia na área do parque ou a utilizava como fonte de extrativismo e de cultivo de lavouras, que provocou muitos ressentimentos. Em consequência, houve uma grande resistência dessas pessoas para se reaproximarem da área patrimonializada.

Ao eleger apenas o homem pré-histórico, pertencente a um passado distante, como elemento integrante da natureza, desconsidera-se a presença e memória dessas pessoas e, principalmente, sua liberdade de transitar pela área sem ser vigiados. Ademais, ao designar apenas o turismo como atividade econômica para a região, declarando as terras improdutivas para a agricultura e criação de animais, desconsidera-se também todo o saber fazer da população rural.

A visão contemporânea reconhece a presença do homem, no passado e no presente, como elemento da paisagem ou da sua formação. A partir de demanda da própria população, essa visão exerce alguma influência nas ações e projetos relacionados ao PARNA SC, incorporando a presença do homem como partícipe da vida na Serra, em uma espécie de combinação híbrida entre as duas concepções de preservação. Assim, surgiram os projetos educacionais da FUMDHAM.

\section{Referências Bibliográficas}

ALMEIDA Fernando Ozorio de; KATER, Thiago. As cachoeiras como bolsões de histórias dos grupos indígenas das terras baixas sul-americanas. Rev. Bras. Hist. vol. $37 \mathrm{n}$. 75. São Paulo, maio/ago. 2017. p. 39-67.

ARRUDA, Rinaldo. Populações tradicionais e a proteção dos recursos naturais em unidades de conservação. Ambiente e Sociedade. 1999, n.5, p. 79-92. Disponível em: <https://www.scielo.br/pdf/asoc/n5/n5a07.pdf> Acesso em 03 out. 2020. http://dx.doi. org/10.1590/ S1414-753X1999000200007

BERQUE, Augustin. Les Raisons du paysage. De la Chine antigue aux environnements de synthèse. Paris: Éditions Hazan, 1995. 192 p.

BRASIL. Decreto $n^{\circ} 7.387$, de 9 de dezembro de 2010. Institui o Inventário Nacional da Diversidade Linguística e dá outras providências. Disponível em: http://portal.iphan gov.br/uploads/ckfinder/arquivos/Decreto\%207387\%20-\%202010.pdf. Acesso em: 13 mai. 2021
BORGES, Jóina Freitas; SANTANA, Jaime de. Sociedade, Arqueologia e Patrimônio: As relações de pertencimento da Comunidade Zabelê com a área arqueológica do Parque Nacional Serra da Capivara (PNSC). História. Unicap, v. 2, n. 3, p. 108-121, jan-jun. 2015. Disponível em: http://www. unicap.br/ojs/index.php/historia/article/view/579/504. Acesso em: 17 mai. 2018. https://doi.or BRASIL. Ministério da Cultura. Decreto $n^{\circ} 3.551$, de 4 de agosto de 2000. Institui registro de bens culturais de natureza imaterial que constituem o patrimônio cultural brasileiro, cria o programa do patrimônio imaterial e dá outras providências. [Brasília], IPHAN, 2000. Disponível em: http://portal.iphan.gov.br/uploads/legislacao/ Decreto n 3.551 de 04 de agosto de 2000.pdf.Acesso em: 20 mai. 2021.

BRASIL. Ministério da Cultura. Decreto $n^{\circ}$ 7387, de 9 de dezembro de 2010. Institui - Inventário Nacional de Diversidade Linguística e dá outras providências. [Brasília], IPHAN, 2010. Disponível em: http://portal.iphan.gov.br/uploads/ckfinder/arquivos/Decreto\%207387\%20-\%202010.pdf.Acesso em: 20 mai. 2021.

CALEGARE, Marcelo Gustavo Aguilar; HIGUCHI, Maria Inês Gasparetto; BRUNO, Ana Carla dos Santos. Povos e comunidades tradicionais: das áreas protegidas à visibilidade política de grupos sociais portadores de identidade étnica e coletiva. São Paulo: Ambiente \& Sociedade, v. XVII, n. 3, p. 115-134, 2014

CÂMARA, Rafael Sette. História e luta dos maniçobeiros no Piauí. 360Meridianos. 26 abr. 2019. Disponível em: https://www.360meridianos.com/especial/ciclo-manicoba. Acesso em: 18 set. 2019

COLLOT, Michel. Poética e filosofia da paisagem. Tradução de Ida Alves et al. 1. ed. Rio de Janeiro: Oficina Raquel, 2013.

COSGROVE, Denis. A geografia está em toda a parte. In: CORRÊA, Roberto Lobato \& ROSENDAHL, Zeny (Org.). Paisagem, Tempo e Cultura. Rio de Janeiro: EDUERJ, 1998. DIEGUES, Antonio Carlos S. O mito moderno da natureza intocada. 6. ed. Ampliada. São Paulo: Hucitec; Núcleo de Apoio a Pesquisa sobre Populações Humanas e Áreas Úmidas Brasileiras: USP, 2008.

FALLEIRO, Rodrigo de Moraes; SANTANA, Marcelo Trindade; BERNI, Cendi Ribas. As Contribuições do Manejo Integrado do Fogo para o Controle dos Incêndios Florestais nas Terras Indígenas do Brasil Revista Biodiversidade Brasileira - BioBrasil. 2016 n. 2 . Número temático: Manejo do fogo em áreas protegidas. ICMBIO, 2016. p. 88-105.

FOGAÇA, Edson. Serra da Capivara (Dir.). Edson Fogaça. Produção: Renan Montenegro. Produção executiva: Rodoferrô. Direção de fotografia: Patrícia Sardá. Roteiro: Edson Fogaça. Trilha sonora: Hamilton Pinheiro. Coordenação: Representação da UNESCO no Brasil. 2013. Documentário. (40 min.). Disponível em: https://www.youtube.com/watch?$v=9576 \mathrm{H}-\mathrm{X} 39 \mathrm{~J} 8 \&$ feature $=$ youtu be Acesso em: 16 maio 2018.

FOUCAULT, Michel. Sobre a Arqueologia das Ciências. Resposta ao Círculo de Epistemologia. Arqueologia das ciências e histórias dos sistemas de: pensamento/Miche Foucault; organização e seleção de textos Manoel Barros da Motta; tradução Elisa Monteiro. 3. ed. Rio de Janeiro: Forense Universitária, 2015.

FUMDHAMentos. São Raimundo Nonato - Piauí: FUMDHAM, 1996-2020. Disponível em: http://fumdham.org.br/pesquisas/\#post-136. Acesso em 12 mai. 2021.

GODOI, Emília Pietrafesa de. O trabalho da memória [manuscrito]: um estudo antropológico de ocupação camponesa no sertão do Piaú. Dissertação (Mestrado em Antropologia) - Instituto de Filosofia e Ciências Humanas da Universidade Estad Campinas. Campinas, 1993.

GUIDON, Niède. A Fundação Museu do Homem Americano e o Parque Nacional Serra da Capivara: um relato sucinto de quatro décadas de pesquisa. In: PESSIS, Anne Marie; 
MARTIN, Gabriela; GUIDON, Niède (Org.). Os Biomas e as sociedades humanas na Pré -História da região do Parque Nacional Serra da Capivara, Brasil, V. II-A, p. 27-44. São Paulo: A\&A Comunicação, 2014.

ICMBIO. Plano de Manejo do Parque Nacional Serra da Capivara. Brasília (DF): ICMBIO, 2019.

IPHAN. Processo de Tombamento da Serra da Capivara. v. 1. Arquivo Central IPHAN

Seção Rio de Janeiro, 1992. Processo de Tombamento n. 1.322 - T- 92. Documentação abrangendo o período de 1990-1993. 1992.

IPHAN. Paisagem Cultural. Brasília, DF: Depam, 2009. Disponível em: http://portal.iphan. gov.br/uploads/ckfinder/arquivos/Livreto_paisagem_cultural.pdf. Acesso em: 10 jun.

2019.

LANDIM, Joseane Pereira Paes. Serra Branca dos maniçobeiros [manuscrito]: um conjunto habitacional sob rocha que (sobre)vive na memória. 2014. 96 f.: il. Dissertação (Mestrado) - Instituto do Patrimônio Histórico e Artístico Nacional, Mestrado Profissional em Patrimônio Cultural. Rio de Janeiro, 2014. 48 f.: il.

LEITE, A. F. O lugar: Duas Acepções Geográficas. Anuário do Instituto de Geociências UFRJ, 21, p. 9-20,1998.

MAIOR, Paulo Martin Souto. Patrimônio arqueológico, ambiente e inclusão social no plano diretor de São Raimundo Nonato. Síntese dos biomas e das sociedades humanas da região do Parque Nacional Serra da Capivara-Pl; v. 3. São Paulo: 2016. 208 p.

MOREIRA, E. V.; HESPANHOL, R. A. M. O lugar como uma construção social. Revista Formação (Presidente Prudente), n. 14, v. 2, p. 48-60, 2007.

OLIVEIRA, Ana Stela de N. Catingueiros da Borracha [manuscrito]: Vida de Maniçobeiro no Sudeste do Piauí 1900/1960. 2001. Dissertação (Mestrado) - Recife: Universidade Federal de Pernambuco, 2001.

OLIVEIRA, Ana Stela de N. Catingueiros da borracha [manuscrito]: Vida de Maniçobeiro no Sudeste do Piauí 1900/1960. São Raimundo Nonato: FUMDHAM/PETROBRÁS, 2014.

OLIVEIRA, Ana Stela de Negreiros; NEGREIROS, Rômulo Macêdo Barreto de; ASSIS, Nívia Paula Dias de. A presença indígena no Sudeste do Piauí: registros históricos, cultura material e o discurso oficial. In: PESSIS, Anne Marie; MARTIN, Gabriela; GUIDON, Niède (Org.). Os Biomas e as sociedades humanas na Pré-História da região do Parque Nacional Serra da Capivara, Brasil, V. II-B, p. 808-832. São Paulo: A\&A Comunicação, 2014 OLMOS, Fábio; BARBOSA, Maria Fátima Ribeiro; ANDRADE, Rute Maria Gonçalves de. Biodiversidade no Holoceno: a fauna. In: PESSIS, Anne Marie; MARTIN, Gabriela; GUIDON, Niède (Org.). Os Biomas e as sociedades humanas na Pré-História da região do Parque Nacional Serra da Capivara, Brasil, V. II-A, p. 207-234. São Paulo: A\&A Comunicação, 2014.
OLMOS, F. et al. Correção política e biodiversidade: a crescente ameaça das populações tradicionais à Mata Atlântica. In: ALBUQUERQUE, Jorge L. B. et al. (Ed.). Ornitologia e conservação: da ciência às estratégias. Tubarão: Unisul, 2001. Disponível em: file:///C:/ Users/USER/Downloads/Olmos_Correopoltica\%20(1).pdf. Acesso em: 1 jun. 2020.

PENA, Belisário; NEIVA, Artur. "Viagem Científica pelo Norte da Bahia, Sudoeste de Pernambuco, Sul do Piauí e de Norte ao Sul de Goiás". In: Memórias do Instituto Oswaldo Cruz. Rio de Janeiro: Instituto Oswaldo Cruz, 1916. p. 1-179. Disponível em: http:// www.scielo.br/scielo.php?script $=$ sci $\_$arttext\&pid=S0074-02761916000300001. Acess em: 25 ago. 2019

PESSIS, Anne Marie. Imagens da Pré-História. 2. ed. P.:il. color; $24 \times 30 \mathrm{~cm}$. FUMDHAM, 2013, $319 \mathrm{p}$.

PESSIS, Anne Marie; MARTIN, Gabriela; GUIDON, Niède (Org.). O Homem na Pré-história do Parque Nacional Serra da Capivara. In: Os Biomas e as sociedades humanas na Pré-História da região do Parque Nacional Serra da Capivara, Brasil, V. II-B, p. 438-440. São Paulo: A\&A Comunicação, 2014.

PESSIS, A-M.; CISNEIROS, D.; MUTZENBERG, D. Identidades Gráficas nos Registros Rupestres do Parque Nacional Serra da Capivara, Piauí, Brasil. FUMDHAMentos, vol. XV, n. 2, p. 33-54, 2018

PROUS, André. Arqueologia brasileira / André Prous. Brasília, DF: UnB, 1992. 613 p. RODA VIVA. Niède Guidon. TV Cultura. YouTube Vídeo Editor. Exibido em 29 set. 2014 Disponível em: Acesso em: 21 jul. 2019. Disponível em: https://www.youtube.com/watch?v=AXa2e5AcU0E. Acesso em: 21 jun. 2019.

SANSOT, Pierre. "Le principe de visibilité» Variations paysagères. Paris: Payot \& Rivages, 2009, pp. 35-59. LOPES, M.B. (org.) Paisagem, Belo Horizonte, NEHCIT, 2019.

SANTOS, Milton. Da totalidade ao lugar. 1. ed. 3. reimpr. São Paulo: Edusp, 2014 SANTOS, Milton. A Natureza do Espaço: Técnica e Tempo, Razão e Emoção. 4. ed. 2. reimpr. São Paulo: Editora da Universidade de São Paulo, 2006.

TUAN, Yi-Fu. Topofilia: um estudo da percepção, atitudes e valores do meio ambiente. Tradução de Lívia de Oliveira. São Paulo: DIFEL, 1980. 260 p.

TUAN, Yi-Fu. Espaço e lugar: a perspectiva da experiência. Yi-Fu Tuan. Tradução de Lívia de Oliveira. São Paulo: DIFEL, 1983.

UNESCO. Decisions adopted by the 27th session of the World Heritage Committee in 2003. Paris: World Heritage Centre, 2001

ZEDEÑO, Maria N.: BOWSER, Brenda J. The Archaeology of Meaningful Places. In:

BOWSER, Brenda J.: ZEDEÑO, Maria N. (Ed.) The Archaeology of Meaningful Places. Salt Lake City: University of Utah Press, 2009. p. 1-14. 
Diva Maria Freire Figueiredo

Universidade Federal de Minas Gerais -UFMG, Escola de Arquitetura- EA

https://orcid.org/0000-0003-2000-3586

divamff@gmail.com

Myriam Bahia Lopes

Universidade Federal de Minas Gerais -UFMG, Escola de Arquitetura- EA

https://orcid.org/0000-0003-4146-4058

bahialopesmyriam@mac.com

Apoio: FAPEMIG APQ-02775-15

Nota do Editor

Recebido em: 01/03/2021

Aprovado em: 09/06/2021

Revisão: RMO 